\title{
Improving Learning Outcomes in Physical Education, Sports and Health (PJOK) Rhythmic Gymnastics Materials through the Application of the Discovery Based Learning Model for Class XI Science 1 SMA Negeri 1 Ceper Academic Year 2021/2022
}

\author{
Mufti Hidayat ${ }^{1, *}$ Sujarwo Sujarwo ${ }^{1}$ \\ ${ }^{I}$ Faculty of Sport Sciences, Universitas Negeri Yogyakarta, Yogyakarta, Indonesia \\ "Corresponding author.Email: muftihidayat.2021@student.uny.ac.id
}

\begin{abstract}
This study aims to improve student learning outcomes in class XI IPA 1 SMA Negeri 1 Ceper in the PJOK subject with Rhythmic Gymnastics material, in the odd semester of the 2021/2022 school year. The subjects of this study were students of class XI IPA 1 SMA Negeri 1 Ceper Odd semesters, totalling 35 people. This research is a classroom action research conducted in two cycles. Each cycle consists of 2 meetings and consists of: planning, implementing actions, observing, evaluating, and reflecting. Data on student learning outcomes were collected through student learning activity observation sheets and assessment of PJOK subjects. The data that has been collected was analysed using descriptive analysis. The results of this study indicate that the application of the Discovery Based Learning Model in PJOK learning can improve student learning. The results achieved in this Classroom Action Research are: 1). Learning outcomes in the first cycle average value $=70$. Complete learning achieved by students $=70 \%, 3$. Learning outcomes in cycle II average value $=79$. Complete learning achieved by students $=95 \%$. Based on the research data and discussion, it can be concluded that the application of the Discovery Based Learning model in PJOK learning can improve learning outcomes Complete learning achieved by students $=95 \%$. Based on the research data and discussion, it can be concluded that the application of the Discovery Based Learning model in PJOK learning can improve learning outcomes Complete learning achieved by students $=95 \%$. Based on the research data and discussion, it can be concluded that the application of the Discovery Based Learning model in PJOK learning can improve learning outcomes student learning outcomes of class XI IPA 1 SMA Negeri 1 Ceper well. Student responses are very positive towards the application of the Discovery Based Learning model, because students can participate actively and the learning atmosphere is very pleasant.
\end{abstract}

Keywords: Discovery Based Learning, Improving Learning Outcomes, Physical Education, Rhythmic Gymnastics Materials, Application

\section{INTRODUCTION}

Teaching is one of the activities used by teachers to make students learn. In the teaching and learning process, students become subjects or actors of learning activities [1]. Using activities have a significant effect on teaching and learning because students can gain experience on their own, build good relationships, work based on their own interests and abilities, develop understanding, think critically and develop personal aspects, so that the activities carried out become more enjoyable. Learning is a change from bad attitudes and behavior for the better, from those who lack knowledge to become more knowledgeable, from those who do not understand to become more knowledgeable. A student is said to be learning if there is a change in his own personality even though it takes a long time to get it. These changes can be in the form of skills, habits, understanding, achievements, interests, and adjustments [2]. It can be concluded that learning activities are a series of learning activities carried out by students 
Education is an obligation that must be carried out during the teaching and learning process. With various activities in learning activities, students are expected to be able to build their own knowledge of mathematical concepts with teacher guidance [3]. The results of observations made showed that student activities during learning were still far from what was expected. maximum results. This is due to the conventional learning process, so students only listen to the lecturer's explanation. Students become passive lack of participation and learned knowledge. Seeing these problems, fundamental changes are needed that can guide students to find concepts and involve students to be active in the learning process [4].

Quality human resources can only be realized with quality education. Quality education is education that is able to develop the positive potentials hidden in students. With quality education, education produces strong potential young workers who are ready to compete in the world community. Therefore, efforts to improve the quality of education are non-negotiable in order to improve the quality of the Indonesian nation's resources [5].

To achieve the expected quality of education, anticipatory, creative and innovative steps are needed. In addition to improving the implementation and monitoring of the eight national education standards, steps that can be taken include creating a conducive environment, good climate, good work culture, job satisfaction, and motivation from leaders who are role models for their subordinates. The principal as a leader should prioritize the management of living things, namely humans, because the school is a Human Resources (HR) factory that humanizes humans. The focus on people in this school is related to the principal's leadership [6].

In recent decades the educational approach has increasingly moved towards a more student-centered approach of which Discovery Learning is a part. The reason for this is that it has been found to instill curiosity and motivation in students to analyze and understand the information they encounter [7]. This again results in better knowledge retention [8]. While expository teaching is based on the teacher (who is believed to be an expert in the field) planning and presenting information within a set time frame, it is generally in an atmosphere where students are passive listeners [9].

Educational theory is the foundation and starting point in the development of educational practice, for example curriculum development, school management and teaching and learning processes. Curriculum and learning have links with educational theory or in the preparation of a curriculum and this lesson plan refers to educational theory [10]. by every citizen. Education should also be carried out as early as possible in order to improve the quality of life. The existence of physical education, sports, and health (PJOK) in schools is needed, not only to improve children's physical fitness, but also to provide varied and beneficial movement experiences for students. Not only that, PJOK contains elements of values that are important in life.

The purpose of national education in the Law of the Republic of Indonesia Number 20 of 2003 concerning the National Education System (Sisdiknas) is to develop the potential of students to become human beings who believe and are devoted to God Almighty, have noble character, are healthy, knowledgeable, capable, creative, independent, and become a democratic and responsible citizen. One way to develop student potential is through education through learning activities. Therefore, the role of the teacher can direct students through learning activities.

In general, PJOK teachers are the main actors in the teaching and learning process in PJOK. Every PJOK teacher must be competent and expected to be able to provide the best for students, especially since the government has issued the latest curriculum in 2013, namely the 2013 curriculum. In its implementation, not all learning models are suitable for use in the latest curriculum at this time, in the 2013 Curriculum there is already a learning model developed with a scientific approach where this becomes the standard of the learning process in the 2013 curriculum [11]. Education is a complex activity, and includes various components that are closely related to each other. Therefore, if education is to be carried out in a planned and orderly manner, the various factors involved in education must be understood first. Various components in the education system, both micro and macro studies need to be identified in depth so that these components can be functioned and developed in order to optimize the educational work towards achieving the educational goals set [12].

Education is more than just teaching, which can be said as a process of knowledge transfer, value transformation, and personality formation with all the aspects it includes. Thus teaching is more oriented to the formation of specialists or certain fields, therefore the attention and interest is more technical [13].

Physical Education, Sports and Health (PJOK), is one of the lessons carried out at the elementary, secondary and even higher education levels. The purpose of physical education is to develop aspects of physical fitness, movement skills, critical thinking skills, social skills, reasoning, emotional stability, moral action and aspects of a healthy lifestyle [14]. 
The National Education Standards Agency (BSNP), in the syllabus model for Physical Education subjects at the basic education level [15], stated that Physical Education, Sports and Health taught in schools has an important role, namely providing opportunities for students to see firsthand in various learning experiences. through physical activities, sports and health that are carried out systematically provide learning experiences to foster better physical growth and psychological development, as well as form a healthy and fit lifestyle throughout life [16].

Physical education, sports and health are media to encourage physical growth, psychological development, motor skills, knowledge and reasoning, appreciation of values (mental-emotional-sportivity-spiritual-social attitude) and physical fitness for students. Learning is designed to teach students, meaning that students are placed as learning subjects. In other words, learning is more oriented to student activities to obtain learning outcomes in the form of a combination of cognitive, affective, and psychomotor aspects proportionally. Some student activities can be directly observed and some cannot be observed directly, such as doing assignments, discussing, and collecting data. The level of student activity is not only determined by physical activity, but also by non-physical activities such as mental, intellectual, and emotional. Therefore, whether or not students are active in learning, only the students themselves know for sure.

For a student, physical fitness is very important to maintain health in carrying out daily tasks as students in improving their learning abilities and achievements. Children who have good physical fitness will be able to receive the knowledge conveyed by the teacher to the maximum, so that it is hoped that their learning achievement can be optimal. Physical education is basically a learning process through systematic physical activities that aim to improve physical fitness, increase knowledge, get used to healthy and active living behavior, and sportsmanship.

Physical education is an important part of the education system. To achieve the goals of education as a whole, physical education must be carried out properly and correctly in an educational institution. In addition, physical education is one of the compulsory subjects in schools from the elementary level (SD and SMP) to the high school level (SMA and SMK) as well as in higher education, because physical education is included in the educational curriculum. Physical education is an integral part of the total educational process. The purpose of Physical Education is to develop physical, mental, emotional and social fitness through physical activities. Thus, it aims to improve individuals organically, neuromuscularly, intellectually and emotionally through physical activity. Meanwhile, the teacher as a motivator and facilitator, has an important role in providing meaning and meaning for PJOK learning and as a means or tool [18].

Becoming a professional physical education teacher is not as easy as many people imagine so far, the wrong perception is that physical education teachers only have whistles and balls at school. On the contrary, to become a professional physical education teacher is more difficult than being a teacher of other subjects. Physical education subjects have more complex problems than other subjects. Therefore, teachers who do not have a physical education profession are asked to teach physical education subjects or vice versa. The physical education teacher profession is generally the same as other subject teachers in general, but in particular has a difference and this is its own characteristic. Character is the values of human behavior related to God Almighty, oneself, fellow human beings, environment and nationality which are manifested in thoughts, attitudes, feelings, words and actions based on religious norms, laws, manners, culture and customs. customs. Building the character of students can be integrated in learning in every subject related to norms or values in each subject that needs to be developed, made explicit, linked to the context of everyday life thus, learning character values is not only at the cognitive level. , but touches on internalization and real experiences in the daily lives of students in society [19]. Environment and nationality which is manifested in thoughts, attitudes, feelings, words and actions based on religious norms, laws, manners, culture and customs. Building the character of students can be integrated in learning in every subject related to norms or values in each subject that needs to be developed, made explicit, linked to the context of everyday life thus, learning character values is not only at the cognitive level., but touches on internalization and real experiences in the daily lives of students in society [19]. Environment and nationality which is manifested in thoughts, attitudes, feelings, words and actions based on religious norms, laws, manners, culture and customs. Building the character of students can be integrated in learning in every subject related to norms or values in each subject that needs to be developed, made explicit, linked to the context of everyday life thus, learning character values is not only at the cognitive level. , but touches on internalization and real experiences in the daily lives of students in society.[19]

In Permendiknas Number 22 of 2006 concerning Content Standards, Physical Education, Sports and Health, it is intended that students have the following abilities. Develop self-management skills in an effort to develop and maintain physical fitness and a healthy lifestyle through selected physical activities and sports. Promotes better physical growth and psychic development [20].

Improving basic movement abilities and skills Laying a strong moral character foundation through 
internalizing the values contained in physical education, sports and health Developing sportsmanship, honesty, discipline, responsibility, cooperation, confidence and democracy,

Develop skills to maintain the safety of oneself, others and the environment, Understand the concept of physical activity and sports in a clean environment as information to achieve perfect physical growth, healthy lifestyle and fitness, skilled, and have a positive attitude.

Physical fitness which includes muscle strength, muscle endurance, heart and lung endurance, strength and balance, speed and agility, all of which are related to the health aspect. While physical fitness is related to performance aspects, namely coordination, agility, speed, and balance

A fact that occurs in the field where when students are asked to perform movements related to the basic techniques of Rhythmic Gymnastics which is one of the discussions on basketball game material, students tend to do it less than perfect, as a result the activities of the PJOK subject for class XI IPA 1 semester are odd. his motor skills to perform these movement exercises can not be done optimally. Thus the results obtained about the subjects

Physical education, sports and health with basketball game material in terms of movement techniques, obtained results below the KKM standard. Likewise, when the pre-cycle evaluation of this material is carried out, the results obtained are 68 with learning mastery reaching $25 \%$, this is still low and below the physical education target.

Achievement and improvement of sports achievements Basketball is increasing at the national, regional and international levels, the improvement and achievement of achievements in the sport of basketball is of course through the efforts of athletes, sports experts and coaches. The sport of basketball is one of the games that must be given to high school students, both junior high school and senior high school. In secondary schools, basketball is one of the most popular sports for students [21].

In general, PJOK teachers are the main actors in the teaching and learning process in PJOK. Every PJOK teacher must be competent and expected to be able to provide the best for students, especially since the government has issued the latest curriculum in 2013, namely the 2013 curriculum. In its implementation, not all learning models are suitable for use in the latest curriculum at this time, in the 2013 Curriculum there is already a learning model developed with a scientific approach where this becomes the standard of the learning process in the 2013 curriculum [22].

PJOK subjects have an important role in the formation of a complete human being, including on the health side through a variety of physical activities that can be done. In accordance with the definition of physical education according to Law No. 3 of 2005 concerning the National Health System, namely education towards harmony between body growth and mental development and is an effort to make Indonesia proud to be a healthy and strong nation physically and mentally, given in all types of schools ranging from Elementary School (SD) to High School (SMA). Furthermore, in the 2013 curriculum which uses a scientific approach, it combines two approaches, namely inductive and deductive approaches where this approach plays an important role in terms of proving and discovering concepts in learning [23].

Where in learning, students use a number of theories that have been obtained previously to be correlated with observations made by themselves in the field, which are expected to become students' new knowledge. The scientific approach in the 2013 curriculum is a learning approach that prioritizes creativity and students' ways of making discoveries in overcoming problems. From new things such as the scientific approach in the 2013 curriculum, that is one of the reasons that underlies the author to conduct this research. Because in addition to the Graduate Competency Standards (SKL) and Content Standards (SI), other components that are undergoing development in the 2013 curriculum are process standards.

According to Mulyasa [24] in learning activities the teacher is only a facilitator, not the main source for students. The task of the teacher as an educator is to try to provide various kinds of learning experiences so that students can find out for themselves about something that is being studied. Something that is learned must be seen, heard, and done by the students themselves.

Based on the author's three observations and interviews in the pre-study in July 2021 with the PJOK teacher of SMA Negeri 1 Ceper, students often found individualists, did not have personal responsibility for the movement tasks given by the teacher, then some students also tended to be closed to friends, so only friends with certain friends. This behavior was found during PJOK learning, the results of the interview concluded that there were still many students who had not been able to solve the problems that existed in learning [25].

If problems like the above are left without any real action to improve attitudes and learning patterns, students will become less characterized in knowledge, attitudes and skills. As stated in Permendikbud No. 103 [26] regarding the learning process there are three recommended learning models in learning using a scientific approach, including Discovery Learning, Discovery Based Learning, and Project Based Learning. In choosing the three models, it must be in accordance with the themes and basic competencies that students 
must master later, and the model chosen must be in accordance with the circumstances and initial abilities of students, time, learning resources and teacher support capacity.

Discovery Learning where the teacher's role is more on the line of being a facilitator helping students to find information by deduction and construction. The main initiators of this learning approach were Bruner based on their constructivist learning theory and Hilda Taba's curriculum-based project on Discovery Learning in the 1960s. Light, Calkins in his book Learning and Teaching in Higher Education, states that one of the most prominent and important challenges in teaching in universities today is the necessity for teachers to realize and accept that only presenting what is planned in advance. information to a passive audience is not sufficient to motivate students to independently "achieve and construct their own knowledge during and after higher education" [26].

Discovery learning is a student-centered model, on the other hand the teacher supervises and guides students in learning. In addition, the discovery learning model also encourages students' desire to learn, allows students to be creative, and organizes the learning process in their own style. Therefore, students are involved and have self-motivation in learning. Bruner describes two objectives of discovery learning, namely (1) discovery learning theory should act as a soft extension theory based on large, individual-oriented constructs; (2) learning theory should serve as a way to define and provide an independent learning structure so that it can serve as a guide for educational research. There are four components of Bruner's discovery learning theory: (1) curiosity and unstable moments; (2) knowledge structure; (3) sorting; and (4) motivation. Based on Nurrohmi, there are 3 principles related to Bruner's discovery learning theory: (1) teaching based on experience and context that encourages students to learn (readiness); (2) organized teaching so that it will be well understood by students; (3) manageable instructions for extrapolation and filling of gaps [27].

One of the teaching materials developed is a discovery learning-based module. This module can activate students in learning. They will think and find out the findings. Then there is student self-satisfaction that can support students to find new concepts being studied, so that student interest increases. Based on the direction of the curriculum, the curriculum should be student-centered. This means that the lecturer only becomes a facilitator and motivator. states that the important steps taken in effective discovery learning based learning modules are first to define the problem given to students with adequate and clear data, second from the data provided by the teacher, the student set, the process. , organize, and analyze, the data, the three Students set the predictions and the analysis performed, fourth If necessary, the predictions made by students are checked by the teacher, fifth if certainty is owned, verbal predictions are left to students to be determined, sixth after students find what is being studied, the teacher must provide exercises or additions to check the results. Through discovery learning is expected to increase student activity in the learning process. [physics conference]

Based on the description above, it is necessary to conduct a study that aims to improve student learning outcomes in PJOK lessons. Especially on basketball material. One of the efforts made by researchers is to conduct classroom action research that aims to improve student learning outcomes in PJOK lessons. In this study, the material selected was a basketball game in accordance with the material that needed to be improved, so that the overall title that the researchers chose was "Improving Learning Outcomes in Physical Education, Sports and Health (PJOK) Rhythmic Gymnastics Materials through the Application of Discovery Based Learning Learning Models with Tik Media. Tok for Class XI Science 1 SMA Negeri 1 Ceper Academic Year 2021/2022"

In this study, the researchers used class XI IPA 1 students as research subjects to improve student learning outcomes. This is based on the observations of researchers for 1 semester, from a number of students in class XI IPA 1 who have advantages or advantages in their hobbies or pleasures and even excel in playing basketball where their hobbies, pleasures and advantages. Researchers listen that students of class XI IPA 1 have advantages in the field of attitude that is already good, where interest and some even have talent in the game of basketball which is the basis for this Class Action Research. However, there are some children in class XI IPA 1 who are not maximal in performing the movement parts, especially in the Rhythmic Gymnastics movement that was raised in this Class Action Research. Likewise, in the game of basketball, intelligence and dexterity are needed in playing the ball, so from a number of students who are the subjects in this Class Action Research, there are still students who are less than optimal in absorbing information that is knowledge and skills in the game of basketball. Therefore, through this Classroom Action Research Researchers will make improvements to students whose understanding is still low can be compared with the abilities of students with higher abilities so that in the end the students' abilities become equal and even.

In this study, the researchers chose the solution of the Discovery Based Learning Learning Model as a solution to improve learning outcomes/students, considering the learning model of Discovery Based Learning the syntax/steps of learning are as follows: 1) Delivering learning objectives, 2) teachers applying 
problem-based learning models, 3) The teacher guides students in training to play basketball by using various thinking skills of students, individually and in groups because in basketball games intelligence is needed in playing, 4) Students will be able to adapt quickly to the environment, 5) Students are guided to able to solve problems independently and intelligently, 6) provide opportunities for students so that the knowledge they receive is meaningful,relevant and contextual and its application in subsequent learning activities

The learning syntax above must be followed in its entirety. Therefore, when applying the Discovery Based Learning learning model, the teacher must fully understand the meaning of each syntax phase. Likewise, students will have a handle to train themselves to imitate and allow students to learn multidimensional and indepth events; develop high-level/critical scientific thinking skills; in playing basketball because there are many dimensions and strategies that need to be trained for students to look for opportunities and opportunities to put the ball into the opponent's basket. Furthermore, the teacher as a facilitator must have the opportunity to check and correct the mistakes and shortcomings of students.

With the application of the Discovery Based Learning learning model, the teacher helps students to reflect or evaluate the results that have been achieved by students and how the strategies and processes that have been understood and can be applied in learning both theory and learning.

\section{METHOD}

This research was conducted in Class XI IPA 1 SMA Negeri 1 Ceper, which is located at Kajen Village, Kec. Ceper, Kab. Klaten Prov. Central Java. This class is a class who's Physical Education, Sports and Health scores have not reached above the class average, or are still low. Besides that, the researcher is also a PJOK teacher in Class XI IPA 1 SMA Negeri 1 Ceper, so that the implementation of the research is carried out in the class being taught. The research subjects were 35 students, with 20 female students and 15 male students. The class was used as a research subject because the average initial test results (pre-cycle) with an average value of 63 and learning completeness reached $25 \%$, so it needed to be addressed immediately.

This research was conducted in the academic year 2021/2022. Do as much as 2 cycles. Each cycle consists of 2 meetings. Learning is carried out by applying the Discovery Based Learning learning model in an effort to improve student learning outcomes.

The implementation of this Classroom Action Research consists of two cycles, where each cycle consists of four components, namely:

\subsection{Planning Phase (Planning)}

At this stage, the researcher prepares a lesson plan (RP), the main material in the subjects of Physical Education, Sports and Health, which will be taught to students along with the indicators. Implementation In cycles I, II, are planned in this preparation. Furthermore, the selection of problems that have the potential to be raised in this research or according to the title that has been approved in this Classroom Action Research proposal. Implementation of the Preliminary Study, formulate the problem, choose the approach to be applied in this research, then determine the variables and determine the data source. Preparing tools and materials is important in this research, and the preparation of competency test instruments and observation sheets.

\subsection{Implementation of the action (Acting)}

The activities carried out at this stage are carrying out learning according to the learning scenarios that have been set in the lesson plans.

\subsection{Observation (Observation)}

At this stage, an observation process is carried out on the implementation of the action using an observation sheet that has been prepared, in accordance with the objectives of the assessment aspect, which includes 3 domains, namely: attitudes, knowledge and skills demonstrated by students.

\subsection{Reflection (Refleting)}

Each cycle is interrelated and related, because the results of the reflection will be used as a reference for improvement in the next cycle. It is expected that each cycle there is a significant increase in the learning of Physical Education, Sports and Health with the ability to improve PJOK learning outcomes, to improve the quality of learning so that the learning outcomes achieved by students are in accordance with the learning objectives. Researchers make changes and improvements in the implementation of learning in each cycle. By looking at changes in student attitudes so that the increase in learning outcomes for PJOK subjects, students can observe their development in each cycle. Data collection using instruments consists of: a) written test, b) observation sheet, and c) interview. After the data is collected, it is continued with the analysis of the research data. Analysis of research data in this study used descriptive statistical analysis. Indicators of success in this study are: if each student achieves a minimum score for attitude: good, knowledge and skills of at least 75 . 


\section{RESULTS}

The learning carried out in the first cycle has achieved an increase in student learning outcomes in Physical Education, Sports and Health lessons on the material for the Rhythmic Gymnastics movement. The learning outcomes achieved by students showed a better improvement than the pre-cycle assessment results. Based Learning where students are able to interpret the concept of Rhythmic Gymnastics subject matter in PJOK subjects, through the application of the Discovery Based Learning learning model. The results achieved in the first cycle are as follows.

The average value of the first cycle $=72$; Student learning completeness $=72 \%$; Students who have not completed $=28 \%$.

\section{DISCUSSION}

In the first cycle the students showed their independence and responsibility towards the tasks given by the teacher well. Students diligently do the exercises exemplified by the teacher and the teacher observes the students carefully. Then the teacher provides continuous guidance with students who can do it correctly until they reach proficiency in performing Rhythmic Gymnastics movements.

When learning, of course, not all students can be involved. Therefore, for students who are used to doing movements, the teacher assigns them to participate in assessing the abilities of their friends. Thus the teacher will be greatly helped and the assessment can be carried out more effectively. In the first cycle, it turns out that in the attitude aspect, all students have succeeded in achieving the research indicators. This is not strange, because these students of class XI IPA 1 live in the village with their parents. The daily lives of these children can still be supervised and help their parents. It is very different from children who live apart from their parents every day. So that these children are still very easy to manage.

In the aspect of knowledge in this first cycle there are children who get relatively low scores, namely six (6) students got a score of 60 from the completeness indicator 64. After the researchers interviewed it turned out that these students lacked interest in reading and their understanding in capturing the material contained in the textbook was still lacking.

Likewise, as many as 6 students who got a score of 60 they will also make improvements in the next cycle but they have good practice skills.

While in the aspect of skills, although there are still 8 children who have not finished, the scores they get are still slightly below the research indicators. Thus to achieve research indicators is not so difficult for teachers to improve.

The achievement of results in cycle II based on the application of the Discovery Based Learning model can be described as follows.

$\mathrm{R}$ average on the value of cycle II $=79$; Student learning completeness $=100 \%$; Unfinished students $=$ $0 \%$

The increase in the results achieved by students in cycle II was due to maximum reflection through the application of the Discovery Based Learning learning model in learning. Students feel their ability to be developed to be proficient in performing Rhythmic Gymnastics. From the value data of the evaluation results of class XI IPA 1 SMA Negeri 1 Ceper, in cycle II which has shown an increase, and there is a positive influence on the application of the Discovery Based Learning learning model, in learning Physical Education, Sports and Health subjects. Thus, the application of the Discovery Based Learning learning model has proven its success well. The results of this study are in line with the results of research conducted by Wahyuni (2017) with the title The Effect of the Discovery Based Learning (DBL) Learning Model on PJOK Learning Outcomes of Class 12 High School Students. In the results of the study, it was concluded that the Discovery Based Learning (DBL) learning model had an effect on the learning outcomes of PJOK for 12th grade high school students at Polan 1 High School in the 2016/2017 academic year. Furthermore, the results of research conducted by Lestari (2016) with the title The Effect of Discovery Based Learning and Project Assessment on Students' Critical Thinking Ability. Based on the results of data analysis, it can be concluded that there is an effect of the DBL model and project assessment on the PJOK's critical thinking ability. In the results of the study, it was concluded that the Discovery Based Learning (DBL) learning model had an effect on the learning outcomes of PJOK for 12th grade high school students at Polan 1 High School in the 2016/2017 academic year. Furthermore, the results of research conducted by Lestari (2016) with the title The Effect of Discovery Based Learning and Project Assessment on Students' Critical Thinking Ability. Based on the results of data analysis, it can be concluded that there is an effect of the DBL model and project assessment on PJOK's critical thinking skills. In the results of the study, it was concluded that the Discovery Based Learning (DBL) learning model had an effect on the learning outcomes of PJOK for 12th grade high school students at Polan 1 High School in the 2016/2017 academic year. Furthermore, the results of research conducted by Lestari (2016) with the title The Effect of Discovery Based Learning and Project Assessment on Students' Critical Thinking Ability. Based on the results of data analysis, it can be 
concluded that there is an effect of the DBL model and project assessment on the PJOK's critical thinking ability.

\section{CONCLUSION}

The conclusion that can be drawn based on the research that has been done is that the application of the Discovery Based Learning Learning Model can effectively improve the Learning Outcomes of Physical Education, Sports and Health (PJOK) for Rhythmic Gymnastics for Class XI Science 1 Odd Semesters at SMA Negeri 1 Ceper, Academic Year 2021/ 2022

Based on the conclusions above, the following suggestions can be put forward. It is suggested to teachers of SMA Negeri 1 Ceper, especially teachers of Physical Education and Health (PJOK) that in an effort to improve student learning outcomes, appropriate and relevant learning models need to be implemented. The application of the Discovery Base Learning model is proven to be able to stimulate students' enthusiasm in learning. Presumably, the Discovery Base Learning model can be continued in Learning Activities. For schools to prepare more game tools. The Department of Education would like the results of this research to be used as a guide in learning physical education, sports and health, especially in Rhythmic Gymnastics.

There is a significant influence of the discovery learning model in the 2013 curriculum on the learning outcomes of Rhythmic Gymnastics in class XI students of SMA Negeri 1 Ceper. It is proven by the results of the pre-test and post-test mean differences using the dependent t-test formula which produces a tcount of $20.73>$ ttable of 1.699 with a significant level of 0.05 .

The influence of the discovery learning model in the 2013 curriculum on the learning outcomes of Rhythmic Gymnastics in class XI students of SMA Negeri 1 Ceper is $61.73 \%$.

\section{REFERENCES}

[1] Hosnan, M. 2014. Scientific and Contextual Approaches in 21st Century Learning. Bogor: Ghalia Indonesia.

[2] Nurkholis. 2013. Education in Efforts to Advance Technology. Journal of Education, Vol. 1 No. November 1, 2013

[3] Permendikbud, 2014. Assessment of Learning Outcomes by Educators in Primary and Secondary Education Number 104 of 2014. Jakarta: Kemdikbud

[4] Y Haryono and R Yusri 1. 2017. International Conference on Mathematics and Science Education (ICMScE) IOP Publishing IOP Conf. Series: Journal of Physics: Conf. Series 895012003 doi
:10.1088/1742-6596/895/1/012003 Effectiveness of Discovery Learning-Based Transformation Geometry Module R Febriana1,a), Mathematics Education Study Program, STKIP PGRI West Sumatra, Jl. Mount Pangilun, Padang 25143 , Indonesia 1-5

[5] Widodo. 2013. Improving Learning Activities and Student Learning Outcomes Using the Discovery Based Learning Method for Class Viia Mts Negeri Donomulyo Kulon Progo Students in the 2012/2013 Academic Year. Indonesian Journal of Physics No: 49, Vol XVII, April 2013 Edition.

[6] Djihadah, Nuryati. 2020. Emotional Intelligence and Leadership of Madrasah Principals in Applications for Strengthening Character Education (PPK) in Madrasahs. Journal of Madrasah Education, Volume 5, Number 1, May 2020 .

[7] Hartini, S. (2019). Professional Competence of Teachers in Improving Student Achievement Motives: Studies at SDN Karangpucung 04 and SDN Karangpucung 05, Cilacap Regency. Indonesian Journal of Education Management \& Administration Review, 3(1), 71-76.

[8] Lestari, Ni Made Sri Ayu. 2016. The Influence of Discovery Based Learning Model and Project Assessment on Students' Science Critical Thinking Ability. Journal of the Pulpit PGSD Undiksha Volume 4 Number 2.

[9] TOJET: The Turkish Online Journal of Educational Technology - November 2016, Special Issue for INTE 2016 Effects Of Discovery Learning And Student Assessment On Academic Success Nilgün $\mathrm{S} 8 \mathrm{P}+\varnothing$ School of Computing and Technology Eastern Mediterranean University Turkey Hüseyin YA5ATAN Faculty of Education Cyprus International University Turkey 829-835

[10] Sholichah, Aas Siti. 2018. Educational Theories in the Qur'an. Journal of Islamic Education Journal of Islamic Education Vol. 07/No.1, April 2018.

[11] Permendikbud, 2014. Learning Process Number 103 of 2014. Jakarta: Kemdikbud.

[12] Sutrisno. 2016. Various Approaches in Values Education and Citizenship Education Journal of Education and Learning Dimensions Vol. 5 January 2016.

[13] Nurkholis. 2013. Education in Efforts to Advance Technology. Journal of Education, Vol. 1 No. November 1, 2013.

[14] Permendikbud Number 22 of 2016 concerning Standards for Primary and Secondary Education 
Processes. Jakarta: Minister of Education and Culture of the Republic of Indonesia Khan, Badrul. (2005).

[15] Permendikbud, 2014. Assessment of Learning Outcomes by Educators in Primary and Secondary Education Number 104 of 2014. Jakarta: Kemdikbud

[16] Permendikbud Number 22 of 2016 concerning Standards for Primary and Secondary Education Processes. Jakarta: Minister of Education and Culture of the Republic of Indonesia Khan, Badrul. (2005).

[17] Widodo, Heri. 2015. A Portrait of Education in Indonesia and Its Readiness in Facing the Asian Economic Community (Mea). Journal of Scholars Vol. 13 No. 2, July - December 2015.

[18] Ministry of Education and Culture. 2013. Teacher's Book of Physical Education, Health, Sports and Health Class XI. Jakarta: Balitbang.

[19] Syahrin, Alfi. 2017. The Role of Physical Education Teachers in Shaping Students' Characters at Mts throughout Banda Aceh for the 2016/2017 Academic Year. Scientific Journal of Physical Education, Health and Recreation Students, Faculty of Teacher Training and Education Unsyiah Volume 3. Number 2.

[20] Permendikbud, 2014. Learning Process Number 103 of 2014. Jakarta: Kemdikbud.

[21] Rubiana, Faith. 2017. The Effect of Learning Shooting (Free Throw) With A Rope Stretch Tool on Shooting (Free Throw) Results in Basketball Games. Journal of Siliwangi Vol. 3. No.2, 2017.

[22] Ministry of Education and Culture. 2013. Permendikbud Number 81a of 2013 concerning Curriculum Implementation. Jakarta: Minister of Education and Culture of the Republic of Indonesia Kemendikbud.

[23] Ministry of Education and Culture. 2013. Permendikbud Number 81a of 2013 concerning Curriculum Implementation. Jakarta: Minister of Education and Culture of the Republic of Indonesia Kemendikbud.

[24] Mulyasa, E. 2002. Competency-based curriculum. Bandung: Rosda Karya.

[25] Cintia, Nichen Irma et al, Application of the Discovery Learning Model to Improve Creative Thinking Ability and Student Learning Outcomes,https://doi.org/10.21009/PIP.321.8.

[26] Ida Ayu Made Trisna Dwi Jayanti . 2021. The Art of Teaching English as a Foreign Language, Vol .1
No. 22021 p-ISSN : 2656-8942, e-ISSN : 2684854613 The Art of Teaching English as a Foreign Language The Use of Discovery Learning in Improving Students' Critical Thinking Ability (A Literature Review) Ganesha Education University, Bal.

[27] Intan Novalia Putri Utami1*, R. Teti Rostikawati2 ,Suci Siti Lathifah. 2021. Journal of Biology Education Research (JBER) https://journal.unpak.ac.id/index.php/jber, The Effect of Discovery Learning Model Towards Biology Problem Solving 1Student of Biology Education Study Program, FKIP, Pakuan University, Bogor, Indonesia 2Lecturer of Biology Education Study Program, FKIP, Pakuan University, Bogor, Indonesia.

[28] Wahyuni . 2017. The Influence of Discovery Based Learning (DBL) Learning Outcomes on PJOK Learning Outcomes of 12th Grade Senior High School Students at Polan 1st Senior High School 2016/2017 Academic Year. Thesis: Sebelas Maret University.

[29] Lestari. 2016. The Influence of the Discovery Based Learning Model and Project Assessment on the Critical Thinking Ability of Class XI Students of SMA 1 Boyolali in the 2019/2020 Academic Year. Thesis: Eleven March University. 